\title{
OSMANLI HUKUKUNDA ZİLYETLİK
}

\author{
İkinci Kisım ( $\left.{ }^{*}\right)$ \\ ZILYETLIK DAVALARI
}

Yazan : Choucri CARDAHI

Çeviren : Asis. Halil ciN

\section{1 - Zilyetlik Davalarmm Türleri :}

Fransız Kanunu, meni müdahale, yedin iadesi ve eski hale getinme olmak üzere üç türlü zilyetlik davası kabul etmektedir. Bunlara ara sıra başka zilyetlik davaları da eklenmektedir. Ancak bu davaların mevcut olmadığını kabul etmek hususunda ittifak edilmektedir. Fransız doktrini, aynı kaidelere tabi üç şekli olan tek bir zilyetlik davasının mevcut olduğunu hararetle müidafaa etmek. tedir. Aksine, mahkeme içtihatlar, bir birinden farklı üç zilyetlik davasının mevcut olduğunu ve yedin iadesi davası ile eski hale getinme davasının, müdahalenin meni davasının tâbi olduğu kajdelerden ayrı kaidelere bağlı olduğurı ileri sürmektedir.

Osmanlı Hukukunda kaç türlü zilyetlik davası vardır? Sulh Hakimleni Kanunu, 24. maddesinde, ancak iade-i yed davasmdan bahsediyor. Bununla beraber Mecelle'nin sustugu hallerde müracaat edilmesi gereken Islam Hukuku prensipleri, az cok karakterize olmuş fakat müiahalenin menine yaklaşık gibi görünen def-ül taarruz adlı bir dava kabul ediyor. Bu dava bidayet mahkemesinin görevine girip, 15 sene sonra zaman așımına uğrar; zilyetliğin ihlâli halinde açllabilir.

Def-ìl taarruz davası dıșında, Sulh Hâkimleri Kanununun, iștimalinin ihlali halinde sulama hakkını himaye etmek için bir zil-

(*) 1926 tarihinde La Revue critique de législation et de jurisprudence da yayınlanmıs olan bu makalenin I. kısml, tarafımızdan Türkçeye çevrilerek, Ankara Hukuk Fakültesi Dergisinin XXII n XXIII cildinde yayınlanmıştır. 
vetlik davası bahșettiğini zikretmek gerekir. Bu, sulama irtifak hakkına has, Sulh. Hakimleri Kanununun, bu iki davanın tatbik sartları bakımından aralarında hiç bir fark gözetmiyerek tanzim ettiği yedin refi davası ile aynı șartlara tâbi müdahalenin meni davasının bir nevidir.

Menị müdahale davası hakkında söylenenlerden sonra, aşağıdaki incelemeler, Sulh Hakimleri Kanunu tarafindan teferruatlı bir șekilde düzenlenmiș olan zilyetlik davalarına ait olacaktır. Bunlar, Yedin iadesi ve sulama irtifak hakkina ilișkin men'i müdahaledir.

Bu arada, Misir Kanunlarmnn da meni müdahale, yedin iadesi ve eski hale getirme olmak üzere üç türlü zilyetlik davası kabul ettiğine işaret edelim.

\section{2 - Istimali Zilyetlik Davalariyle Himaye Edilen Haklar :}

Fransız Hukukunda, zilyetlik davası maliklik durumundan fiilen istifade eden kimseye verilmiștir. İstimali zilyetlik davalany. le korunan irtifak haklair, prensip olarak, Fransız Medeni Kanununun zaman aşım ile iktisap edilmesine cevaz verdiği irtifakların aynıdır. Bu zilyetlik davaları, intifa, kullanma hakkı gibi șahsi irtifak haklarına da uygulanır. Devamlı ve aynî olan irtifak haklarına gelince, bunlar zaman aşımı bakımından yeterli bir zilyetlik yardımiyle iktisap edilmeye müsaittirler. Istimalleri, bir senede ve bir tile babasının tahsisine istinat etmese bile, zilyetlik davalariyle himaye edilmektedir. Ancak zaman aşımı ile iktisap edilen fasılasız ve alenî olmayan irtifak haklarnna gelince; zilyetlik davacısı, zilyetli. gine dayanarak hadim gayrmenkulün malikinden sadır olan bir senet ibraz ettiği zaman, bu senet, fasılalı irtifakların zaman aşımına uğramazlı̆̆ından çıkan tolerans hükmünü bertaraf eder. Bundan, bahis konusu irtifak haklarmın bir senede istinat ettikleri zaman, üçüncü şahısların tecavïzlerine karşı zilyetlik davalariyle himaye edilmiş olduğu neticesi çıkar.

Osmanl ${ }_{1}$ Hukukunda himayesi için bir zilyetlik davası tanınmış olan irtifak hakkı, sulama irtifak hakkı (hakel şurb) (1) ve sulama irtifakının değișik bir șekii olan içme suyu alma hakkı (hak el choffa) dır. Süphesiz ki bu sulama irtifakı alenidir.

(1) Hak el şurb, hayvanları sulamak ve sulama faaliyetleri için kullanılmak üzere su almak hakkıdrr. 
Devaml kat öyle görünüyor ki, Fransız içlihatları böyle bir irtifaka devamlllık vasfı tanımıştır; çünkü istimali için, nihai olarak insanın şimdiki fiilini nazarı itibara almadığından dolayı, böyle bir jrtifaka devamlilik karakteri tanumaktadır (2).

Zaten bu noktayı teorik bir gaye ile tetkik ediyoruz. Gerçekiten bir irtifakm devamlı yahut fasılalı, alenî yahut alenî olmadığını bilmek vakıası, Osmanlı Hukukunda ehemmiyeti haiz değildir. Zira, irtifak hakkı bu karaktere sahip olsun olmasin, 24. maddenin ifadesine göre, irtifak hakkın tesis eden ve kullanılmasının ihlalinden evvel, bu haktan istifade edildiğini doğrulayacak bir senet ibraz etmek şarttır. Fransız Hukukunda durum böyle degildir. Senet, ancak fasılalı bir irtifak hakkı bahse konu olduğu zaman istenir; diğer faraziyelerde, zilyetlik vakıası ziyetlik davası hakkı bahșetmeye yeterlidir.

Diğer taraftan, İslâm Hukuku, devamlı irtifaklarla münkati irtifak hakları arasında bu ayrımı yapmış gibi görünmüiyor (3).

Fransız Hukuku, etrafı çevrildiği takdirde geçiş hakkını bir zilyetlik davasıla himaye etmektedir. Osmanlı Hukukunda, bu irtifak ancak sadece bir mülikiyet davası açılması imkanını verebilir.

\section{3 - Zilyetlik Davalarunın İstimal Șartları}

Fransız Hukukunda bu şartlar buitün zilyetlik davaları için aynı değildir. Mahkeme içtihatları daha az sert görünüyor ve yedin iadesi davasının kabule şayan olması için, müdahalenin meni yahut eski hale getirme davasındaki kadar fazla şant aramiyor. Yedin iadesi davasının kabule şayan olması yolunda aranılan sartları tetkik etmek için, men'i müdahale ve eski hale getirme davasinın istimal şartlarını kısaca izah etmek gerekir:

Men'i müdahale ve eski hale getirmeye taallûkk eden şartlar, bilindiği gibi üç tanedir :

1. - Zilyetlik, zaman așımı ile iktisap için lûzumlù șartları uhidesinde toplamahdır.

(2) Voir Cass. 6 Nov. 1871 D 72. I. 299 - Voir également arrêt de la Cour d'Appel mixte d'Egypte du 10 avril 1901. Bull. XII, P. 23.

(3) Voir en ce sens Morand, op. cit., P. 370 et arrêt de la Cour d'Alger du 24 janvier 1891 dans Rev. Alg. 1892,2, 267. 
2 - Zilyetlik bir sene devam etmeli. olmalıdır.

3 - Zilyetlik davası, ihlâlden itibaren bir sene içinde açılmış

Birinci Şart: Zilyetlik devaml olmalı, yani anormal inkıta olmaksızın ve tasarruf konusu șeyin mahiyetine uygun fiiller vasitasiyle gerçekleșmelidir.

Zilyetlik münkati olmamalı yani fasılasız olarak bir sene devam etmelidir.

Zilyetlik nizasız olmalıdır; yani eski zilyedi şeyi terk etmeye mecbur eden maddi cebir (zor kullanma) ve manevi cebir (ağır ve ciddi tehditler) le ihlal edilmemiș olmalıdır.

Zilyetlik malik sifatiyle olmalı; ve bir șey malik olma niyetiyle elde bulundurulduğu zaman; başka bir deyimle, fiili hakimiyete (conpus) a animus domini eklendiği zaman, malik sıfatıyla tasarrut edilmiş olur.

Nihayet zilyetlik şüphesiz olmall; yani yukarda izah edilmiş olan bütün vasfflan itiraz kabul etmez bir șekilde uhdesinde toplamalıdir.

Ikinci Şart : Incelediğimiz vasıfları haiz olan zilyetlik, bir men'i muidarale ve eski hale getirme davasının temeli olabilmek için 1 se. ne devam etmelidir.

Uçünciu Şart: Bu șant 23. maddeden çıkmaktadır; zilyetlik davaları, ihlalden itibaren ancak bir sene içinde açlldıklan takdirde kabule sayan olurlar.

Fransız Hukukunda yedin iadesi davasına gelince: Uzun bir tereddütten sonra, mahkeme içtihatlannda kesin olarak takarrür etmiş olan sistem şöyledir: Yedin jadesi davasının kabule şayan olması için ne bir senelik zilyetliğe ne fasılasız ve malik sıfatiyle zilvetliğe ihtiyaç vardrr. Sadece elde bulundurma, yani nizasız ve alenî olmak şartiyle, maddi ve fiili bir zilyetlik yetişir.

Yedin iadesi davası, zilyetlikten mahrumiyetten itibaren bir senelik süre içinde ikame edilmiş olmalıdır.

Böylece, büyük bir yazarın işaret ettił̧i gibi, bu son içtihat, zilye:llił̧in himayesinin şümulï konusunda Fransız Hukukunu, hiç olmazsa biraz muistakil olan ve zilyetliginde bulunan șey üzerinde az 
çok bir hakimiyete sahip bulunan vazülyetleri kanumun himaye ettiği zilyetler arasında sayan Alman ve İsviçre Medeni Kanunlarına yaklaştırmıștır (4).

Şimdi Osmanl Hukukuna geçiyoruz: Bu paragrafa gę̧meden önce, zilyetlik davalarınm bu tarzının, șimdiye kadar hiç bir doktriner incelemenin konusu yapılmadığna yeniden işaret etmekte fay. da vardır. Bununla beraber, kanun hükümleri yakından incelenerek onları esinleyen genel düşünceleri ortaya çıkarmak ve görünüşte, mantıken eleştirilmemiş bir sistemnden çıkmış gibi görünmeyen dağJnk hükümleri teorinin çerçevesi içine sokmak mümkündür.

Sulh Hakimleri Kanumu tarafından öngörülmüiș olan zilyetlik davalannın istimal șartları, Fransız Hukukundan farklı olarak, ileride göreceğimiz bir istisna hariç, aynıdır.

Osmanl Kanunu, zilyetlikten mahrum edilme (izale-i yed) halini nazara almaktadır. Bu, yedin iadesi davasının açlldığı mutad haldir. Ancak yedin iadesinin şu iki karekteri gösterdiği söylenebilir :

Gerçekten, Fransız Hukukunda meni muidahale, prensip olarak, zilyedi zilyetliŏgine karşı vukubulmuş ihlallere karşı korumaya ma'uf olduğu halde, yedin iadesi, cebir yahut şiddet neticesi zilyetlikten mahrumiyet halini icabettirir.

Osmanlı Hukukunda, kanun iki nevi yedin iadesi davası kabul ediyor:

Zilyetlikten mahrumiyet halinde açllan yedin iadesi davası vardir; bu mahrumiyet, siddet yoluyla (bu kelimeyi en hafif manasinda alarak) keyfi bir fiil, haksı bir hareket netiossinde vukubulmalidir.

Ve bu yedin iadlesinin yanında, kanun, kuvvet kullanma yahut tehdit suretiyle zorla tasarrufitan mahrumiyet halinde açlan bir başka yedin iadesi davasının mevcudiyetini kabul etmektedir. Bu sonuncu davada, kanun koyucu, gayet açıç̧a belli edilmiş taarruzî bir fiil istiyor gibi görïnmaktedir.

Bu konuda Osmanlı Hukukunu, Hollanda Kanununun hükü̈mlerine yaklaștırmak mümkündür (5). Halbuki alelıtlak yedin iadesi

(4) V. Glasson et Tissier, Traité théorie et pratique de procédure civil, ze édition, P. 525.

(5) V.C. civil de Hollande, art. 618. 
davası, cebirle zilyetliğinden mahrum edilmiş zilyedi himaye eder. (V; art. 619).

Şimdi, șiddet yoliyle zilyetlikten mahrumiyet halinde açilan yedin iadesi davasma mukabil basit yedin iadesi davası diye adlandı ı̆ımız davanın istimal șartlarını tetkik edelim :

A) Basit Yedin ladesi : Basit yedin iadesi davasunda kanun şunlar1 istiyor :

1 - Bir zilyetlik olmal.

2 - Bu zilyetlik malik sifatiyle olmals.

3 - Ve Fransız kanunundan farkl olarak, kanun, zilyetlik da: vasının süresi içinde açlması gerektĭ̌̀i hiç bir özel müddet tayin ctmemiştir.

Birinci Şart: Tabiidir ki, zilyetliǧinin iadesini isteyen davacınnn, herhangi bir zilyetliğin mevcudiyetini isbat etmesi gerekir. Zil. yctlik nizasız olmalıdır; çünkii zilyetlik bir cebir neticesi doğmuşsa, tecaviuzün mał̆duru tarafundan açlacak bir yedin iadesi davasına cevaz verilmiş olurdu.

Dił̌ger taraftan, zilyetlik alenî olmalıdır. Çünkü bu zilyetlik ha. rici fiillerle açığa vurulmazsa, davacı muissterek hukukun isbat vasitalariyle fiili hakimiyetini nasil isbat edebilirdi?

Fransız Hukukunda meni muidahale davası bahse konu olduğu zaman, zilyetliọ̆in iadesini isteyen kimsenin bu zilyetliği hiç olmazsa bir sene devam etmiș olmalıdır.

Osmanlı Hukukunda basit yedin iadeși davası için durum aynu mıdır? Şüphesiz ki, kanun bir sene devam etmiş olan bir zilyetijk istemiyor. Ancak İslam Hukukunda zilyetliğin uzunca bir müd. det, meselâ 10 aydan beri devam etmesi șartiyle zilyetlik davalariyle himaye edildiğine Morand işaret etmiştir. Moran'dın kanaati, Maliki Mezhebinin buiyuük hukukçularından biri olan Sidi El Khalil'e istinad eder (6).

Bu 10 aylik müddet, Harefi Mezhebirde istenir gözükmüyor; jstenseydi bile, kanun onu zilyetlik davalarının kabule sayan olması için aramazd.

(6) Voir. Khalil, art. 1666; Morand, Avant - Projet du code de droit musulman algérien, P. 462 . 
Ikinci Șart:: Zilyetliğin malik stfatiyle olması gerekir. Kanun koyucu, yukanıda sëylemiş olduğumuz gibi, zilyetlik davasını ihdas ederken, zilyetliği ve sadece vazülyetlik vakıasında tezahür eden zilyetliği değil fakiat malik sıfatiyle bir zilyetliği himaye etmek istemiştir. Bu kcnuda, malik sffatiyle zilyetlik istenen șartlara sahip olunca, bu bölümdeki ısrarı veçhile, bu şekilde kanun koyucu tarafmdan düzenlenen zilyetlik davasmnn, mülkiyet davası alanına tecavüz edip etmediği ve hakkın esasına taallûk eden davayı lùzumsuz kılıp kılmadığı sorulur. Gerçekten de, yedin iadesi davacısı bir mülkiyet senedi ibraz etmeli ve zilyetlikten mahrum edildigini de isbat stmelidir.

Fransız Hukukunda, zilyetlik davasının istimali bakımından malik stafiyle zilyet sayılmak için, bu zilyetliğin bir mülkiyet senedi ilc isbat edilmesi şart olmayıp, sadece şeyi iğreti olarak almamış olmak yetişir (7). Iğretilik mefruz sayılmadığına göre, davacınm bașkası için isgal ettił̆ini ve onun sadece iğreti bir vazülyet olduğunu isbat etmek davalıya düsser.

Osmanl Hukukunda durum aynı değildir. Bu konuda hiç bịr ihtilâf olmadı̆ı̆ halde, bir mülkiyet senedine dayanarak malik sıfatiyle zilyet olduğunu isbat etmek, geçici olarak zilyed olana değil, zilyetlik davacısına düşer. Kanun bu konuda çok titizdir. $O$ ancak ger. çekten mülkiyete vïcut veren zilyetlikleri himaye etmek istemiştir.

Uçüncï Şart: Fransız Hukukunda, zilyetlik davası bir senelik müddet içinde ikame edilmiş olmalıdır. Davacı bir seneyi hareketsiz geçirmişse, zilyetlik davası açinak hakkındar mahrum olur. Bu yalnız zilyetliğin ihlâlinden beri bir yıl geçmesiyle davalının zilyet. liği elde etmiș olması halinde değil, davalının her hangi bir haklı zilyetlik idduasında bulunamadığı hallerde de böyledir.

Zilyetlikk davasının kabule şayan olması için istenen bu bir senelik müddeti, Osmanlı kanun koyucusu Sulh Hakimleri Kanununda hiç bir veçhile belintmeniștir.

Mamafiuh, bakanlar kurulunun talebi ve Devlet Şurrasının muitâalası üzerine, 20 Ramazan 1329 tarihli bir irade ile bu müddet öngörülmüştür. Fakat ne yazık ki böyle davaların muvakkat karaktexi ile ahenk halinde olan bu rejimin kendisi bir seneden fazla devam etmemiştir. Çünkiu 17 Sefer 1330 tarihli bir irade ile, 1329 tarihli

(7) Cass. 23 Août 1884 s. 86 . I. 165 , 
irade ilga edilmiştir (8). Kont Ostroroğ tarafindan teklif edilen Sulh Hakimleri Kanunu öntasarısı, bu bir senelik miiddeti yeniden alacağı yerde, bir seneden pek kisa, bir aylık bir müddeti öngördï (9). Fakat kanunlaşan kati metin hiç bir müddetten bahsstmiyor; öyleki, basit yedin iadesi davası zilyetlikten mahrumiyet tarihinden itibaren, davalarn mutad sukut muiddeti olan 15 sene içinde açılabilir.

Bir aylık müddet belki yetersiz; fakat buna karşılık, 15 senelik müddet de çok uzundur. Kanun zilyetlik davasını süratli bir adalet. ten istifade ettirmek gayesiyle Sulh Hakimlerinin yetkisi dahiline soktư̆u halde, zilyetlik davalarının muistacel olan karekteri kaybolmuştur.

Zaten kanun koyucuların ekserisi, meselâ Iitalyan Kodu, Porteteki Kodu, Şili Kanunu, Arjantin Kodu, Misır Kodu, zilyetlik davasının ikamesi için kısa, ekseriya bir senelik müiddet kabul etmişlerdir. Yalnız Frusya Kodu, sadece ihlâl vakıasının yakın bir zamanda vukubulmasım istemektedir. Bu yakın zaman ise, her davada duruma göre yorumlanmaktadir.

B) Cebir Sebebiyle Yedin Iadesi Hakkinda : Genel olarak, yedin iadeșinin bu çeşidi, Fransız Hukukundaki yedin iadesine çok yaklaşır.

Yedin iadesi, Sulh Hakimleri Kanununun 24. maddesinde şöyle ifade edilmektedir : "Bir kimsenin bâsenet uhdei tasarrufunda bulunan emvali gayrımenkuleye ahân tarafından tecavïz ve müdahale olunarak ihdasi yed edildikte, mutasarrif olan kimse iade-i yed davası ikamesiyle zilyedi hakiki bulunduğunu bâsenet ve ihdası yetden mukaddem münazâaun - fih zilyet olduğunu esbabı subutiye-i saire ile isbat ettikde, yed-i hadisenin refine hükïim olunarak müddaabih yedi kadime sahibine iade olunur. Sahibi senet işbu tariki kanuniye müracaat etmeksizin cebren ve tegallïben gayrımenkulü zabtettiği ve tarafı ahâr dahi müracaat eylediği takdirde, hali sâbikin iadesiyle sahibi senede tariki kanuniye müracaat etmesi tembih olunur.» Bu yedin iadesi davasını karakterize eden şey, kanunsuz ve bizzat ihkaki hak eden failin suçlu olarak kabul edilmesi ve amme intizamma muhalif fiilin tamirinin istenmesidir.

(8) V. Dustour III, P. 738, Dustour IV, IV, P. 87.

(9) Voir. art. 12 l'avant - projet. 
Burada sırası gelmişken şunu da söyliyelim: Osmanlı Kanunu, zorla malından mahrum edilmiș olan kimseye, o anda kuvveti kuvvetle defederek korunmak ve kendi şahsi kuvvetiyle zilyetliğini tesis etmek hakkını kabul etmeye kadar gitmiş midir?

Bir menkul bahse konu olduğu zaman olumlu olarak cevap vermek mümkündür. Kanun, cebir suretiyle menkul bir malından mah. rum edilmiş olan kimseye, zilyetliğine dönmek için sırasında kuvvet kullanmaya müsaade etmiştir (10).

Bununla beraber kanun şu şartı koymaktadır: Bu, kanunun kullandığı hususi deyimle, $O$ anda yetkili merciye müracaat etmek imkânının bulunmamasıdır. Kaldı ki bu łükǜm Islâm Hukukunun prensiplerine uygundur.

Bir gayrimenkul bahse konu olduğu zaman, mesele çok șüphelidir. Mahkeme içtihatları menfi istikamettedir. Güçlük, her zaman olduğu gibi, Osmanlı Hukukunun bu konuda açı' bir hüküm, koymayışından doğmaktadır. Halbuki Alman Kodu (Art. 859), birbirini takibeden iki faraziye kabul ediyor ve iki halde, kanunen yasak edilmiş bir fiille zilyetliğinden mahrum edilmiş kimsenin bizzat ih. kak1 hak etmesine müsaade ediyor.

Arjantin Kodu, 2470. maddesinde, zilyetliğin zilyede, zilyetliø̈ini korumak için yardımın geç ḱalacağı ahvalde, kâfi bir kuvvet istimali suretiyle tecavüzü defetmek hakkını verdiğini derpiş etmektedir. Brezilya Kodu da, zilyetlikten mahrum edilmiş zilyedin, ayn anda olmak șartıyla kuvvetle kuvveti defetmesini kabul etmektedir (11).

Osmanlı Kanunu, yabancı mevzuatın çoğu tarafindan kabul edilmiş olan zilyetlikte meşru mïidafaa konusunda pek vazıh değilse de; bununla beraber, Osmanl kanun koyucusunun, cebren zilyet. lił̌inden mahrum edilmiş olan zilyede toleranslı davrandığı ve gö. receğimiz gibi, ona zilyetlik davasının istimal şartların ehemmiyetli bir şekilde kolaylaştırmış olduğu bir gerçektir.

Böylece cebir sebebiyle yedin iadesi diye adlardırdığımız bu yedin iadesi, Fransız mahkeme içtihatlarının yedin iadesine uyguladı̆̆ hususi ve son derece geniş şartlardan az bir farkla istifade eder. Burada, zilyetlikten mahrum edilmiş olan davacının, nizasız

(10) Argt. tiré de l'art. 130 de Code Pénal Ottoman.

(11) Ord. tir. 4 Art. 58, Parag. 2. 
zilyet olduğunu ve kuvvet yoluyla zilyetliğinden mahrum, edilmiş olduğunu isbat etmesi yeteriidir. Bu zilyetliğin malik sıfatiyle olmas1 şart dę̆ildir. Metinler bu davayı açabilme hakkını vazülyetlere, kiracılara yahut daha başkalarına da tanımaktadır.

4 - Zilyetlik Davalarında Ustul : Fransız Hukukun da «actori incumbit probation kaidesi mucibince, davaci zilyetliğin maddi unsurunu isbat etmelidir. Bir yıllık zilyetliğin ve ihlâlin isłbat edilmesiyle davacinın külfeti sona erer. Adı geçen zilyetliğin devaml olmama, gayn kanunilik, iğretilik ayıplariyle malûl olduğunu isbat etmek hasmı olan davaliya terettuib eder.

Zilyetlik davaları konusunda, müșterek hukukun isbat șekilleri de ayner kabul edilmiștir. Şu halde sthlh hakimi, ister ikrar yahư yemin ister keșif vasıtasiyle, ister bir sorușturma ile ve is. terse mülkiyet senetleri ile olsun hadise hakkında aydınlanabilir.

Osmanlı Hukukunda, Sulh Hakimleri Kantununun 24, maddesine göre zilyetlik davacısı :

1 - Zilyetliginin mesnedi olan müllkiyet senedini ibraz etmeli.

2 Zilyetlikiten mahrumiyet anmda ihtilâfl gayrimenkulün zilyedi olduğunu isbat etmelidir.

A) Mülkiyet senedinin ibrazı, zilyetliğin bir mülkiyet hakkı üzerine inşa edildiğini ve bir bakıma, malik olmak sıfatiyle olduğcunu isbat etmek için kanun tarafından istenmektedir. Fransız Hukukunda, hakim bu senetleri ancak zilyetliğin meşru olup olmadığımı araştırmak ve onu hukuken tavsif etmek için tetkik eder. $\mathrm{Bu}$, genel olarak hasmın, davacının zilyetliğini lekeleyen bir geçicilik iddiası üzerine vukubulur; çünkui evvelce de belirttiğimiz gibi, geçicilik mefruz değildir. Mahalli mevzuatta durum tamamiyle aynı değildir. Davacı, zilyetliğinin haklılık vasfı konusunda, davaIı tarafından hiç bir ihtilâf çıkarılmaması halinde bile senedini ibraz etmeye mecburdur.

Bundan bașka, kanun zilyetlik davasını gören hakime lakkm esası hakkında huiküm vermeyi yasakladığından, bu ibrazın ancak zilyetliği tavsif etmek için konduğuna inanmak gerekir.

B) Bundan başka, davacı zilyetlikten mahrumiyetin vukubuldugu anda zilyet oldıgunu isbat etmelidir. 
Bu vakıa, müșterek hukukun bütün isbat vasıtalariyle, mese. lâ ikrar, yemin, tahkikat ve keșifle bile isbat edilebilir. Bu son usul kaidesi, Sulh Hakimleri Kanunumun bir yeniliğidir. o daha önceleri Osmanlı Hukukunda bilinmiyordu.

5 - Zilyetlik Davalartnda Görev: Bütün davalar, gïrev nok‘ai nazarından su'h hakiminin görevi dahilindedir. Gayrımeıkulün gerçek durum,u hakkında kendisine bașvurulan sulh hakimidir. Bu kaide Fransız ve Osmanlı Hukukunda mïşterektir. Yalnız iki mevzuat arasındaki aşağıdaki farká işaret etmek gerekir. Fransız Kamununa göre, sulh hakimi ihtilât halinde olan menfaatin konusu ne clursa olsun buitü davalara bakaibilir ve kararlarma istinaf yoluyla daima itiraz edilebilir. Halbuki Osmanl1 Hukukunda, sulh hakiminin zilyetlik davaları kenusundaki hükümleri ancak temyiz edilebilir.

Bu hal tarzı tatminkâr mıdır? Osmanlı kanun koyucusu, istinafi kaldırırken, zilyetilik davalarmin faydalılığı konusunda, bazı müelliflerin, bu davaların zilyetlik ve onu takiben miilkiyet konusunda bir ön ihtilâf meydana getirdiği ve bunların kabili istinaf hü. kümlerin verilmesine sebeb olduğu ve bu halin bir kaç karıș toprak hakkında bile zuhur edebileceği tarzındaki tenkitlerini nazara almak mı istemiștir (12)? Bu mümkün fakat zayıf bir ihtimaldir.

Her halükârda, kanun tasarısı, Osmanlı kanun koyucusunu bu yolu izlemeye zorlyyan sebebi göstermemektedir.

Diğer taraftan, kanun koyucunun istinafi kaldırarak bu konuda sürat getirmiesine rağmen, dava zaman aşımı olan 15 senelik muiddet yerine oldukça k1sa bir müdddet, meselâ bir senelik bir müiddet koymayı düșïnmediği nasıl kabul edilebilir?

Bu konuda, Irlanda Kanununun, davacilar bu kanun yolundan mahrum etmeye kadar götuirmeksizin, sürat isteyen genel menfaat ile istinafın garantisini icabettiren fent menfaatini uzlaştıracak bir ölçü kabul ettiğini hatırlatalın. İlanda Kanunu, zilyetlik konusunda verilmiş olan hüikmü istinafa rağmen geçici olarak icrası emredilebilen hükümler arasına koymaktadır.

(12) V. Béranger (Dans les Mémoires de l'Academie des Sciences politiques, t. I, 2 sér. 1837 p. 478) Alauzet conclut seulement à la suppression de l'appel en matière possessoire (p 281 et suiv.) V. Garsonnet, op. cit., t. I, p. 686 . 
6 - Mülkiyet ve Zilyetlik Davastntn Íçtima Edemiyeceği Prensibi: Bir zilyetlik davasın rüyet eden sulh hakimi, kararnnda zil. yetlik ve mülkiyet davasını içtima ettiremez. $O$, sadece zilyetlik da. vası hakkında hüiküm vermelidir. Fransız Usul Kanununun 24. maddesinin emredici şekilde kabul eylediği kaide budur. Gerçekten, sulh hakimi zilyetlik davasın ihmal edip, doğrudan doğruya yahut dolayısiyle mülkiyet meselesini hallettiği takdirde; zilyetlik davası teorisinin nazara alınmıacağ̣ ve kanun koyucunun zilyede vermek istedeği himayenin tamamiyle hayali olacağı şüphesizdir.

Osmanl Hukukunda, hakim için mïlkiyet ve zilyetlik davalarinı içtima ettirme yasağı, Sulh Hakimleri Karununun 5 ve 27. maddelerinden doğmaktadır. Kanun, 5. maddesinde, sulh hakimi «...Esbabı istimalinden menedilmiş olan hakkı şirb davalarını esasa intikal etmeksizin dahi kabili temyiz olhnak üzere rüyet ve hükmeder» kaidesini koymuștur. Yedin iadesi davasında, davalının yeditin refine dair verilen kararn, davacmm ihtilâflı gayrımenkule malik olduğunu tazammun etmiyeceği 27. maddede derpiş edilmektedir.

1 -- Ilk Olarak: Bu yasaklama, Fransız Hukukunda, Osmani Hukukunda olduğu gibi, hakime uygulanabilen ve ikiye irca edilmesi kabil çok sayıda önemli sonuçlar doğurur.

a) Zilyetlik davasına bakan hakim, kararında istihkak davası hakkında hüküm vermekten imtina etmelidir.

b) Zilyetlik davasına bakan hakim, münhasıran hakka dayanan sebeblerle zilyetlik davasm kabul yahut reddetmekten imtina etmelidir.

2 - Ikinci Olarak: Zilyetlik ve istihkak davaları arasında mevcut olan ayrilık, taraflara kabili tatbik olan bir ikinci kaide tarafından ontaya konmuştur. Bu, Fransız. Hukukunda, usul kanununun 26. maddesinde ifade edilmektedir. Bu kaide, taraflarn zilyetlik davalariyle ișe başlamağa mecbur olduklarına işaret ediyor. Taraflar ancak zilyetlik önmeselesinin hallinden sonra, muilkiyet davasına müracaat edebilirler. Bu kaidenin müeyyidesi, önce mülkiyet davası açmıs olan davacınm, sonradan zilyetlik davasına döneme. mesidir. Bu şekilde hakkının kaybolmasına razı olan kimse, artık sulh hakimine başvuramaz. Gerçekten temyiz mahkemesi içtihatlarının son durumuna göre, davacı tarafından doğrudan doğruya mülkiyet davası ikamesi, zilyetlik davasından zımnen feragati ta- 
zammun eder (13). Zilyetlik davası, zilyetliğin ihlâlinin mülkiyeı davasının ikamesinden önce vukubulmus olduğunu tabii farzediyor.

Osmanlı Hukukunda durum aynı mıdır? Mesele nazik ve bazı gelişmeler kaydetmiştir.

Önceleri, mülkiyet davası asliye malıkemesince görüldügü halde, sonradan 25 Temmuz 1325 tarihli bir irade mucibince, vilâyet encümenleri zilyetlik davalannı riiyete bașlamıșlardır.

Zilyetlik davacısı zilyetliğin himayesi yoluna başvuramadan miulkiyet davası ikame etmişse, artık o andan itibaren zilyetlik davısı açmak onun için imkânsız olur. Bu husus, Ş̀̀rayı Devlet tarafindan onanmıs bulunan bakanlık genelgesinden doguyordu. Şüphesiz bu gerelgeler kanun kuvvetine sahip değildi; fakat Sulh Hakimleri Kanununa yapılan dört ilâve onları, zilyetlik davalarmın sulh mahkemelerinin bulunmadı̆̆ yerlerde, idare meclisleri tarafindan ve bu meclislere ilişkin usullere uygun olarak görülecełini kabul ederek, zımnen kanun kuvvetine yükseltti.

Mülkiyet davasının mahkemede olduğu bir sırada idare meclisine müracaat edilmişse, zilyetlik davasının kabule şayan olmadiğına karar vermek gerekir.

Bununla beraber, yukarda işaret ettiğimiz gibi, ihlâl yahut zilyetlikten mahrumiyet, mülkiyet davasından sonra (bu davanın jkame edilmesinden sonra) vukubulmuşsa, șüphesiz ki hiç bir şey davacıyı zilyetlik davası açmaktan menedemez.

Bu fikirler düzeni ile konuyu bitirirken, Fransız Usul Kanununun, 27. maddesinde, zilyetlik davasını kaybeden davalının, mülkiyet davası açmadan önce, aleyhine verilen hükmün icabın tam olarak yapmasinı ve bütün mahkeme masraflariyle birlikte zarar ziyan ödemesini istediğini kaydedelim.

Böyle açık bir hüküm mevcut olmadı̆̆ına göre, Osmanlı Hukukunda, mülkiyet davası açacak kimse, davasının kabule sayan olmaS1 dçin zilyetlik davasında kendisi aleyhine verilen hükmüin icaplarını önceden yerine getirmeğe mecbur mudur? Bu soruya olumsuz cevap verilebilir; çünkü aksi takdirde kanuna başka bir hüküim eklenmiş olurdu.

(13) Cassa. 16 fév. 1877; SIREY; 1883, 1, 462. 
Kald 1 ki, mülkiyet ve zilyetlik davasının içtima edemiyeceği kaidesini benimseyen Mısır Kodu da, 27. maddenin yukardaki hükmünui kabul etmiyor. Aynı şekilde, bı metnin yokIuğunda Misır mahkeme içtihatları, Fransız noktai nazarının aksine olarak, daha önce zilyetlik davasında mahkûm, edilmiş olduğu zarar ziyanları henüz ödememiş olan bir mülkiyet davacısımm davasın kabule şavan clarak kabul etmeyi vazife saydılar (14).

Su halde özet olarak ve ku kısmı bitirirken diyebiliriz ki, yaptığımız tahditler hariç, mevzuatın bu günkï durumunda, Lübnan Temyiz Mahkemesinin de karar verdiği gibi, hakim için olduğg kadar davanın tarafları için de, zilyetlik davası ile mülkiyet davasmı içtima ettirmek yasaktır (15).

\section{Zilyetlik Davalarının Karekteri. Kime Karșt Açtlabilirler?}

Zilyetlik davaları gayrımenkul davalaridır ve ancak gayrımenkullere uygulanir; menkullerde asla tygulanamaz. Bununla beraber, bu son nokta doktrinde ihtilâflıdır. Ancak mahkeme içtihatları daima menfi görüşü savunmuşlardır. Kaldı ki, Dubost'un usul kanunu reform tasarısı, menkulleri sarih olarak zilyetlik davası sahasmdan çıkarmıştır.

Zaten Fransız ve Osmanlı Kodları, bazı şartların tahakkuku halinde menkul zilyetliğini himaye eden bazı yabancı mevzuatlardan, bu cümleden olmak üzere İngiliz ve Venezüilla Kanunlarnndan, bu noktada ayrilmaktadirlar.

Zilyetlik davalan aynî yahut sahsi davalar mıdır? Meselenin pratik önemi şu iki noktada kendini gösterir :

1.- Zilyetlik davaları şahsi ise, ancak ihlâlin ve zilyetlikten mahrumiyetin failine, onun külli haleflerine ve ika edilmiṣ olan gayr!meşru fïlin șerikleri olan cüzi haleflerin mirasçılarına karşı jkame edilebilir. Aksine zilyetlik davaları aynî davalar ise, hakla teçhiz edilmiş olacaklarından, ihlâlin yahut zilyetlikten mahrumiyetin faili olsalar bile, ihtilâfl gayrmenkulün bütün vazülyetlerine karşı ikame edilebilirler (16).

(14) Jugement du Caire dans l'affaire Mosseri et Beheri R. C. 648. 24 Confirmé par l'arret de la cour 12 Mars 1902. V. Lusena. Précis de procédure Egypt P. 149.

(15) V. Arrêt cour de cassation du Gd Liban, en date du 10 juillet 1924, No. 80 .

(16) Bourbeau A. 7 No. 290-291; Aubry et Rau, T.2, p. 168 et 189. 
Müidahalenin meni davasının aynî bir dava olduğunu kabul hususunda, Fransız hukukçuları genel olarak ittifak etmektedir. Müdahalenin meni, zilyetlik hakkın korumak gayesine sahiptir. Öyleyse zilyetlik bir aynî haktır (17).

Yedin iadesi konusunda mesele daha karışıktır. Müelliflerin çoğu, müdahalenin meni davasmdan farkl olarak, yedin iadesinin şahsi bir dava olduğu fikrindedirler. Filhakika, yedin iadesinin bir zilyetlik meselesini halletmediłi kabul edilmektedir. Yedin iadesi, yaratıcı prensibini umumi sûkunu ihlâl eden cebir vakiasında bulur. Yedin iadesi, bilhassa gayrtkanuni bir fiilin tamiri için' tesis edilmiștir. Şu halde yedin iadesi, cürmün önlenmesine matuftur ve böylelikle yedin iadeși șahsi bir dava gibi telâkki edilir.

Osmanl ${ }_{1}$ Hukukunda mesele ne durumdadır ?

Sulama hakkkına (hakkı șirb) taallûk eden.müdahalenin men'i, yukarda izah ettiğimiz sebsbler dolayısiyle, karekterize olmus ayni bir dava gibi gërünüyor. Bu nokta güiclük arzetmez. Fakat mesele, Osmanl Hukukunda yedin iadesinin karakterini tayin etmek ballse konu olduğu zaman nazikleşmeye başlyyor. Bize göre, basit yedin jadesi ve şiddet sebebiyle yedin iadesini birbirinden ayrdetmek ge rekir.

Basit yedin iadesi davası, aynî bir davadır. Filhakika $\mathrm{O}$, ayn̂̂ bir hakkı, zilyetlik hakkin himaye ediyor ve kim clursa olsun gayImenkulün tüitün vazülyetlerine karşı ikame edilebiliyor. Sulh. Hakimleri Kanununun 25. maddesi, evvelce de gördügüumüz gibi, malların bir satış yahut miras gibi bir sebeble üçüncï şahısların ellerine geçmesi halinde, iadesinin talep edileceği faraziyesini isdihdaf ediyor.

Aksine şiddet sebebiyle yedin iadesi, tarifi güç melez bir karektere sahiptir. Bu noktayı açıklığa kavuşturmak için şu iki ihtimali gözc̈nünde bulundurmak gerekir.

Birinci thtimal: Usultine uygun bir senet mucibince tasarrut edilen bir gayrimenkulï, şiddet kullanarak zabteden, sonra onu iyi niyetli bir ügüncii șahsa satan ve elinde senedi bulunmayan bix kimse bahis konudur. Bu hal ne tapu senedi ve nede kadastro bürosunun mevcut olduğu küiçïk Lübran'da ortaya çıabilir. Bu halde, yedin iadesi iyi niyetli vazülyede karșı açlabilir ve mahkeme se-

(17) Aubry et Rau, t.é, p. 168 e 189. 
netlerin tetkiki sonucunda, 25. madde mucibince, zorla zilyetliğinden mahrum edilmiş olan kimsenin lehine karar verir. o zaman yedin iadesi davası aynî bir karakter arzeder.

Ikinci Ihtimal : Burada sağlam. bir senede sahip olan kimsenin, senetsiz tasarruf eden kimsenin yedindeki gayrımenkulü zorla ele geçirmesi ve ona zilyet olduktan sonra, bir üçünciu şahsa satmış olmas1 halini nazara almak gerekir. Senedi olmayan zilyet, 24. maddenin öngörddiuğü şiddet sebebiyle yedin iadesi davasını ikame et. mek hakkınt haizdir.

Bu dava, iyi niyetli kabul edilen ve cebir vakasısında şerik olmayan üçüncü şahıs müktesibe karşı ikame edilebilir mi? öyle geliyorki hayır; ve bu konuda halen mevcut sebebler, Fransız Hukukunda yedin iadesi davasının șahsi karekteri lehinde ileri sürülen sebeblerden daha kuvvetlidir.

Gerçekten, Fransa'da yedin iadesi davası, daha çok gayrıkanunî ve umumi sükûna muhalif bir fiilin tamiri ve fer'i olarak zilyetliğ̣in himayesi için ihdas edilmiștir.

Kantun koyucunun mahalli mevzuatta bu özel yedin iadesi davasmi tesis edenken, bilhassa değil, belki münhasiran, bizzat ihkakı hak eddeni cezalandrrmak maksadına sahip olduğunu söylemek mümkündür. Kanun koyucunun ihdas ettiğgi dava, bir zilyetlik silahı değil, fakat umumi sükûnun bir vasıtasıdır. Öyleki, aynı zamanda halenki davaya vüctıt veren bu faraziye, bizzat ihkak1 hak fiili Ceza kanununun 130. maddesiyle cezalandırılmış olduğundan, cezai takibatlara bile sebeb olabiliyordu.

\section{Zilyetliğe Dair Kararn Ihtiva Ettiği Hüküm :}

Zilyetlik davasını bitiren karar, zilyetlik davasın ya tamæmen yahut kısmen reddedebilir veya tamamen kabul edebilir.

1 - Zilyetlik Davastntn Reddi: Davacı, zilyetlik davasinn kabulü için gerekli hususları yeterli bir şekilde isbat edemediğ takdirde, sulh hakimi talebi reddetmeğe mecburdur.

2 - Zilyetlik Davastntn Kabulï: Zilyetlik ve ihlâli isbat edilmişse, sulh hakimi halin muhafazasma yahut davacım yedinin iadesine karar verecektir. Bundan başka sulh hakimi, davaliyı, talep tarihinden beri toplamış olduğu semerelerin (hatta kötï niyetli olduğu takdirde talep tarihinden önce toplamış olduğu semerelerin) 
jadesine małkûm eder. Bu hal tarzı, Maliki Mezhebinin prensipleriyle bağdasabiliyondu. Yukarda tiebarüz ettirdiğimiz gibi, Sidi el Khalil'in İslâm Hukuku Kodunun 855. maddesi, iyi niyetli zilyedin, kendini zilyetlikten mahrum eden karara kadar topladığı semerelerin maliki olacağını hükme bağlamaktadır.

Aksine Hanefi Mezhebine göre, gasbedilmiş gayrımenkulün endüstriyel semereleri, gasıbın mülkïi olur. Bu prensibin tatbiki cümlesinden olmak üzere, Sulh Hakimleri Kanununun 31. maddesi şt hükmü kcymaktadır: "Yedi hadise sahibi münazaun-fih olan mahalle ziraat edipte mahsul mevsimi idrak etmişse, iadei yed davası usulen sabit cldukda mahsulatın biçerek müddaabihten nefi yed eylemesi mitiddealeyhe emrolunur.»

Biraz evvel gördüğumiüz gibi, zilyetlik davasını kazanan davacı; Mecelle'ni. 907. maddesine göre, hasılat sebebiyle vukubulan krymet dïşmesi için bir tazminatla birlikte arazisini istirdat eylemek hakkına sahiptir.

Sulh hakimi, ihlâle sebebiyet veren şeylerin kal'ini ve işgal edilen yerlerin eski haline getirilmesini emredebilir mi? Doktrinde çğunluk ve mahkeme içtihatlar olumlu anlamda fikir beyan etmek. tedirler. Bu șekilde hareket ederek ve gerekli tedbirleri alarak, sulh hakimi zilyetlik ve miullkiyet davasın içtima ettirir gibi gözükmektedir; fakat bu sadece görünüştedir. Gerçekten işaret etmek gerekir ki, adı geçen tedbirler hakkın esası hakkında hüküm vermek amacını değil, fakat sadece tecavüzden önceki haline getirerek, yahut daha sonra yapılabilecek ihlalleri önliyerek, zilyetliğe hürmet ettirmek' amacını güder. Sulh hakiminin, görevi dıșına çıkmadıkça, kararmda bahis konusu olan tedbirleri emrederek, zilyetlik ve mülkiyet davasını içtima ettiremiyeceği kabul edilmektedir (18).

Sulh hakiminin, davacının talebi üzerine, zilyetliğin ihlali olarak kabul edilen seylerin ve bir tren șefinin gasbettiği toprak üzerinde tesis ettiği çitin kaldırılmasını emretmeye görevli olduŏu kabul edilmiștir (19).

Hatta sulh hakiminin, sadece görevli değil, fakat ihlal teşkil eden şeylerin kal'ini emretmeye mecbur olduğu da kabul edilnıektedir (20). Sadece, davacmin arsası üzerine daval 1 tarafindan ya-

(18) Cf. Belime No. 368; Aubry et Rau, loc. cit; Contra. Garsonnet.

(19) Cass. 30 Janv. 1837, S. 37-1-613; 15 Févr. 1836. S. $38-1-239,2$ Avril 1883. S. 84.1.120; Troplong, t. I, No. 325 et s.; Aubry et Rau, t.p. 161.

(20) Cass. 18 Juin 1866, S. 66.1365. 
pilmış işler söz konusu olduğu zaman değil, fakat aym zamanda bu ị̧ler daval ${ }_{1}$ tarafindan kendi arsası üzerinde yapildığı zaman ve hatta sulh hakiminin bu ișlerin haklı olarak yapıldıklarını kabul etttiği ve davalını mülkiyet davasmı kazanması gerektiği zaman bile durum budur (21).

Temyiz Mahkemesi, hakimin, davalıyı, mülkiyet davasm isbat edememesi sebebiyle, onun tarafından inșa edilmiş duvarı yıkmaya ve șeyleri eski hallerine getirmeye mahkùm etmesi halinde, görevini aşmadığına karar vermekle bu fikirden uzaklaşmış görünüyor (22).

Gerçekten, başkasının zilyetliğini ihlâl eden fiillere teşebbüs eden kimse, haksızdrr. Fakat Mahkemenin arazi hakkında hüküm vermesinden evvel, yapılmış clan şeylerin yıkılmasını emretmek ölçünün en sert olduğu hallerdendir. Kaldıki iște bu sebebten, bu te.dbiri ëngëren 27. maddenin değiștirilmesi ve yapılmış olan șeylerin kali için muayyer bir müddet vermenin, hakim için bir hak olması da istendi (23).

Sulh hakimi, teminat mukabilinde ișlerin devamına bile müsaa de edebilir. (Garsonnet bu görüște)

Hatta gösterildiği gibi, bir başkası tarafından tasarruf edilen toprak üzerinde bazı șeyler yapıldı̆̆ zaman, sulh hakimi zilyedin durumunu muhafaza ederek, sadece toprağın zilyetliğini değil, fakat toprağın fer'i olan eserleri de ona vermeye mecburdur. Mütemmim cüzüne ve eserlerin yapıcisuna terettiip efmekte olan tazminatlarm tesviyesine dair $\mathrm{C}$. Civ. in 555. maddesirin tatbikine gelince; bunlar miilkiyet davasını gören hakime gönderilmelidir. Bu faraziye, zilyetliğinde rahatsiz edilen yahut zilyetliginden mahrum edilen zilyedin, zilyetlik davalısı tarafundan yapılan șeyleri, kendisine ait olan toprak üzerinde bulması halini isdihdaf eder görünmektedir.

Bu meselenin Fransız Hukukunda nasıl çözümlendiğini gördük; şimdi Osmanlı Hukukundaki tanzim tarzını göreceğiz:

Kazai içtihatlara konu teşkil eden hallerin ekserisi, Fransız Hukukunda, müdahalenin meni davasma taallük etmekte ve bu

(21) Bourbeau No.434; Aubry et Rau, 5 ed. t. 2, P. 243; Contra: Belime, No. 367.

(22) Req. 6 Déc. 1871, D.P.72.1.136.

(23) V. Glasson et Tissier, 3 éd. 1925, P. 534. Bazenet, Les actions Posessoires, P. 535. 
içtihatlar, ihlâlin, tamamen bașkasının arsası üzerinde inșa edilmiș bulunan eserlerden doğdugogunu kabul etmektedir. Hakimin, ihlâli sona erdirmek için bu eserlerin ylkılmasını emretmesi normal bir harekettir.

Osmanlı Hukukunda, gerçek müdahalenin meni davası, (mülkiyet davası ile karışan def ül taarruz denilen dava nazara alınmaksızın) ancak sulama irtifak hakkı için öngörülmüştür. Bu özel halin dişında, kanun ancak yedin iadesi davasından bahsetmektedir.

Imdi, sulama irtifakının istimaline vukubulmuș olan ihlali kaldırtmak için, hakim, Fransız hakiminin yaptığı gibi, davacının, bir akar sudan serbest istifadesine zarar veren fiillere karşı korunmasına matuf zilyetlik davasında, ihlâle sebebiyet veren șeylerin $\mathrm{kal}$. dırılmasını emredebilmelidir (24). Y€din iadesi için durum aynı mudır? Kanunun isdihdaf ettił̆i ihtimal, gerçek zilyedin, zilyetliğini elde etmek istediği gasbedilmis toprağın, zilyetlik davalısı tarafından inşa edilmiş binalarla kaplı olduğ zaman mı tahakkuk edecektir?

Bu binaların geleceği ne olacaktır? Fransız Hukukunda, zilyetlik davasında haklı çıkan davacıya, sadece gasbedilmiș toprağın değil, fakat toprağın mütemmim cuizii olan şeylerin de iade edilmiş olduğunu evvelce görmüştük. Zaten, gerçekten arsa üzerinde inşaat yapan kimseye 'terettüp eden tazminatın ödenmesi ve C. Civil'in 555 . maddesinin tatbikine taallûk eden bütün bu meseleler, mülkiyet davasına bakan hakimin görevi içine girecektir.

Çözïim tarzı Osmanlı Hukukunda da aynıdır. Șu manada ki, hakim görevini așmış olmaksızın bu binaların ve ağaçların kaderini., bunları tanzim eden Mecelle'nin 906 ve sonraki maddelerine uygun olarak tayin edemez. Fakat bu çöziim tarzı bir bakımdan farklılık arzetmektedir :

Fransız Hukukunda, zilyetlik davasmı kazanan davaci, toprağ̀ın olduğu kadar, oraya yapılmış olan binaların da zilyedi olmaktadir.

Bu durumda, Osmanl Hukukunda baikis konusu binalar ve ağaçlar, bir aylık bir müddet içinde yetkili nıahkemeye müracaat etmesi ve dava sabit olduğu takdirde, davacimn maruz kalabilece-

(24) Ayn mahiyette: Cass. Fr. 14 Mars 1882. 
Gi zararm tazminini garanti eden bir teminat göstermesi şartiyle, davalının zilyetliğinde bırakılır.

Davalı bu teminatı gösteremediği takdirde, ağaçlar ve binalar, teminat göstermesi şartiyle davacıya tevdi olunur. Her iki taraf da teminat göstemeye muktedir değilse, binalar ve ağaçlar bir yediemine tevdi edilir. Sulh Hakimleri Kanununun 29. maddesi tarafından öngörülen hal tarzı budur.

Tezahür edebilen diğer ihtimaller, meselâ bir bahçe duvaranın yapılması gibi, derpiş ve tanzim edilmemiştir. Bu hale Fransız Huhukukunun çözüm tarzmın tatbikine ve bu eserlerin kal'i için hakime yetki vermeye hiç bir şey mani olmasa gerek.

Şimdiye kadar, zilyetlik davası hakkında verilen kararın ihtiva edebileceği hükümleri inceliyerek, sadece davacının zilyetlik davası ikamesi halini nazara aldık. Fakat sırasında, davalının, kendi zilyetliğinin tanınmasını hakimden istemesi de mümkündür.

Fransiz Hukukunda, taraflarnn her birinin, iddia ettikleri zilyetliği isbat etmeleri kabul edilmiştir. Bir çok ihtimaller ortaya çikabilir :

Birinci Ihtimal: Davacı ve daval, herbiri zilyetliklerini isbat ediyorlar; fakat bu iki zilyetlik, müşterek olarak ihtiláfl gayrımenkulün bütüunüne şamildir. Bu durumda, hakim her iki tarafın zilyetliğinin muhafazasına karar vereceiktir (25).

Benzer bir ihtimal, tamamiyle aynı tarzda, Osmanlı Hukukunda ortaya çıkamaz. Ihtilaf halinde bulunan iki tarafmn iddia ettiği zilyetliğ̣in isbatı, Fransız Hukukunda olduğu gibi, zilyetlik davasının kazanılması için kâfi değildir.

Ostrorog tarafından teklif edilmiş olan Sulh Hakimleri Kanunu tasarısına göre, sadece zilyetliğin isbatı, tek bașına bir zilvetlik davasının kabulïi için yeterli olabiliyordu (26). Fakat ka. nun kuvvetini haiz olan kat'i metine göre, zilyetliğin isbatından sonra, ayrica bu zilyetliłgin bir miilkiyet senedi mucibince vukubulduğunu tevsik' için bir senet ibraz etmek gerekir. Dosyada mevcut senetlerin taaddüidü, ihtilâflı gayrmmenkulün taksim edilmemiş olmasindan doguyorsa, o zaman taraflar Sulh Hakimleri Kanununun

(25) Bourbeau, Art. 7.

(26) Voir. Art. 58 al. 2. 
24. maddesine göre müştereken zilyet olacaklardır. Aynı maddenin son fukrasına göre, «tarafeynin hiç biri tasarruf senedi ibraz etmediği takdirde, esas temellük davasını rüyete mezun mahkemeye müracaat etmeleri tarafeyne ihtar olunur».

Ikinci Ihtimal: Iki taraf zilyetliklerini isbat etmişlerdir; fakat bu iki zilyetlik birbirine hasım ve biri diğeri ile kabili telif degildir. Hakim, ya tarafları müşterek zilyetliklerinde bırakacak yahut mïşterek zilyetlik hakkında karar vermeksizin, ister kayıt\$ı şartsız, is. ter bir haciz tesis ederek, ister muvakkat bir istifade hakkı vererek yani ihtilâflı gayrımenkulün tarafların biri yahut diğeri nezdindo muvakkaten muhafazasına müsade ederek, taraflara mülkiyet davası açmalannı sağlık verecektir.

Fransa'da bu nevi çözüm tarzının ortaya çıkardığ münakaşaya girmeksizin, kazai içtihadın teorisini belirtelim: Içtihat, bu faraziyede, hakimin, ister kayıtsız şartsız, ister haciz yahut muvakkat istifadeyi emrederek bu hususu ele alamryacağın, fakat ister bu zilyetliği taraflardan birine ihale ederek, isterse tarafları halenki zilyetliklerinde muhafaza ederek, zilyetlik meselesi üzerinde kati bir karar vermek durumunda olduğunu savunan milielliflerin çoğunluğunun kanaatinin aksine olarak, tarafları mülkiyet davası açmaya gönderebileceği fikrindedir (27).

Osmanlı Hukukunda mesele nasıldır? Yukardaki faraziyeyi, esaslarını biraz değiştirerek nazara almak gerekir. İki tarafın, zilyetliği isbat etmek için aynı yahut bașka şahıslardan sadır olan, birbiriyle uzlaşmaz ve biri diğerine zut iki mülkiyet (yahut tasarruf senedi) ibraz ettiklerini farzedelim. Bu halde hakim neye karar vermelidir? 25. madddeye göre, hakim, önceki tarihli senedin zilyedine üstünlük vermeli ve bundan başka, zilyetlikten mahrumiyet anında zilyet olduğunu isbat ederse, davasını kabul etmelidir.

Çabuk netice dioğuran bu hal tarzı, hukuk açısından daha az tenkide șayan değildir. Burada kanun koyucu, açık bir şekilde, ikta gibi, mülkiyetin zahiri karinesi gibi bizzat himaye edilmesi gereken zilyetliği değil, fakat mülkiyeti himaye ediyor; vakıa bu hal tarzı, zilyetlik davasın kazanan kimse lehine açıkça bir hak ihdas ediyor ve bu sebeble kanunun derpiş ettiği, "zilyetlik davası ile mülkiyet davasının içtìma edemiyeceği» kaidesini ihlâl ediyor.

(27) Voir Aubry et Rau, t.2. p. 161; Rodiere, t. VII, No. 431 etc.; contra, Carré et Chauveau, t. I, Quest. II; Appleton, 394. 


\section{Genel Düșünceler :}

Bu etüitden açıkça anlaşılacağı üzere, Osmanlı Hukuku, bir sistematizasyon çalışmașına güç̧lükle yanaşmaktadır. Çünküi ekseriya genel fikirlerle idare edilmemektedir. Birbirine baglı meseleler; ara sıra taban tabana zit bir şekilde tanzim edilmektedir. Mecelle incelendiği zaman, kanun koyucunun, hukuku, ekseriya aralarında bir irtibat olmaksızın, sosyal hayatın ortaya çıkardığı çeșitli güiçlüikleIj halletmeye matuf hakkaniyet kaidelerinin bir bütünü olarak nazara aldığı intibaı açıkça ortaya çıkar. Bu hukuk, prensiplere inmeksizin daha çck teferruat üzerinde durmuştur. Bu, genel fikirlerin vetersizliğinden yahut yokluğundan doğuyordu. Bu o derece doğru ki, büyük bir kısmı genel kaideler koyan ve «Kavaid-i Külliye» adı verilen Mecelle'nin ilk 100 maddesi, Mecelle'yi hazırlıanlarm fikrine göre, adaletin tecellisinde esas alınmamalıdır. İslâm hukukçuları, bu prensiplerin basit hükümler gibi malùmat kabilinden incelenmiş olduğu inancundadırlar.

Osmanlı Hukukunun bir başka karekteristiği onun özelliğini teşkil eder.

Genel fikirlerin yckluğu ve Osmanl ${ }_{1}$ Hukukunun bu özellił̆i, evvelce belirtmek firsatını buldugumuz ve șimdi belirtilınesi daha uygun olan kir takım aksi rıeticelere sebebiyet vermiştir. İşte bu anlayıș, hukukun aşırı ferdiyetçiliği dolayısiyle, kanun koyucuyı, ferdi menfaati, umumî menfaatin zararına himaye etmeye götür. nüiştür. Karıın koyucu, iki menfaat arasındaki çatışmada toplumun menfaatinin, daima ferdin menfaatinin üstünde olması gerekliğini gözden kaybediyor gibi görünmektedir.

Işte bunưn içindir ki, kanun koyucu, bir menkulün malikine, malını 15 sene içinde iyi niyetli mïktesibin elinden almak hakkını vermiştir. Bu şekilde Osmanlı kanun koyucusu, bütün ticari haya11 felce uğratacak durumda clan böyle bir ölçüüi kabul etmekte tek başına kalmış bulunuyor. Çünkü, bazı mevzuatlar, menkuller hakında istindat hakkın kabul etmişlersede, hiç olmazsa bu davanın çok kısa bir zamanda, meselâ 3 sene içinde açılması şartını koymușlardır.

Diğer taraftan, mülküinün bir başkası tarafından uzun müddet işgal edilmesi halinde, mülikiyet hakkı sahibi olan kimsenin hakkını kaybetmiyeceği fikri, Mecelle'yi kazandırıcı zaman aşımını tanımamaya, cna kanuni bir mevcudiyet vermemeye götürmïş̧tïr. Mecelle'ye göre, hakiki malik, haksız zilyetler tarafindan hakkına vukubulacak tecavüzlere karșı kendini koruyabilmelidir; bu sonuncuların zil- 
yetliği çok eski zamanlara kadar inmelidir. Yabancı mevzuatlara zaman aşımını kabul ettiren genel ve temel düzen mïlâhazaları itmal ediliyor, ferdin menfaati üstün tutuluyor. Tecrübenin gösterdiği husus șudur ki, uzun zaman devam eden fiili bir durumu ihlal ctmenin çok kötü olduğu ve sasyal düzenin belli bir ölçüde durum. ların değișrnezliği ile ilgili bulundŭgu sabit clmasına rağmen, bu husus Osmanlı kanun koyucusunun gözünden ką̧mıştır. Ve diğer taraftan, şeyini uzun zaman istirdat etmeksizin gayn meșru zilyedin elinde bırakan malik, ihmali sebebiyle hakkını kaybetımișse, mesuliyetini bizzat kendisi yüklenmelidir.

Fakat adaletsizliği tecviz eder göründüğü için, hukuka aykırı olan bu usucapioyu, Osmanlı kanun koyucusu, crvelce etrafl birsekilde gördü̈üümüz gibi, bir usul oyunu ile kabul etmeye yönelmiştir. Osmanlr Hukukunun, prensip olarak zaman așımına muhalif olduğg halde, dolayısiyle ve bazı kaide oyunlariyle zaman aşımını sadoce kabul etmekle kalmayıp, hatta zaman aşımı ile iktisap şeklini kelaylaștırmış olması tuhaflığına işaret etmek yerinde olur. Fransız Hukukında, zaman așımı, haklı seteb ve iyi niyet olmadığı zaman 30 senelik bir zilyetliği icabettirdiği halde, Osmanlı Hukukunda 15 sene sonra benzer bir neticeye vasil olunmaktadir.

Üçüncui Olarak: Kanun koyucunun, meşrû malike hakkinmn tamammı teslim arzusu, kendisine, zilyedin istifadesinin karekterini, iyi yahưt kötü niyetini hiç nazara almayan değișmez bir çöziüm tarzı ilham etmiştir. Bununla beraber, adalet, iyi niyetli zilyedin kaderinin, âdi bir gasıbın kaderinden daha fazla himayeye lâyık olrnasm istemiyor mu?

Mevzuatın delâlet ettiłgi genel fikirlerin yokluğtı meselesine gelince; o, zilyetlik davalarının mülkiyet davalariyle aynı süreye sahip clması mantıksızlı̆̆ırın sebsbidir. Bu, tesirli bir çözüm tarzı değil midir? Zilyetlik davaları, prensip olarak âni durumları tanzim, etneye matuf olmalar sebebiyle, esas itibariyle muvakkattırlar. Meselâ, bir yedin iadesi davasmın zilyetlikten mahrumiyet tarihinden itibaren 15 sere içinde açlabileceği nasıl kabul edilebilir? $\mathrm{Bu}$ davaların istimali için yeter uzunlukta bir süre kabul etmiş olan mevzuatlar arasında Osmanlı Hukuku başta gelir.

Hülasa, böyle bir mevzuat izah edilmeye muhtaçtır. Bazı hususlar hiç şüphesiz muhafaza edilmelidir. Bir kaç kaide, yeniden düzenlenmek ihtiyacında ve diğerlerinden çoğu yenilenmelidir. Türkiye, kanunlarm yeniden gözden geçirmenin örneğini bize verdi bile. Mandeter devletin bu yolı takip edece ğine güvenimiz var. 